Acta Theriologica 35 (1-2): 53 - 67, 1990.

PL ISSN $0001-7051$

\title{
The southern range of the root vole in Poland
}

\author{
Barbara SAŁATA-PIŁACIŃSKA
}

\begin{abstract}
Sałata-Piłacińska B. 1990. The southern range of the root vole in Poland. Acta theriol. 35; $53-67$.

On the basis of the analysis of owl pellets collected in the years 1975-1978 and trapping carried out from 1980 to 1982, the southern range of the root vole Microtus oeconomus (Pallas, 1776 ) in Poland was determined. The root vole was found in the food of owls from 29 localities and in 16 trapping locations situated at the edge of the range. This allowed a more precise determination of the boundary of its occurrence and made it possible to find extreme populations of this species. I was noted that beyond the southern limit of the range of $M$. oeconomus the field vole Microtus agrestis was a much commoner species.
\end{abstract}

Department of Systematic Zoology, Adam Mickiewicz University, Fredry 10, 61-701 Poznań, Poland

Key words: distribution, southern range, Microtus oeconomus, Poland

\section{Introduction}

The root vole, $M$. oeconomus (Pallas, 1776) a species with a wide distribution throughout the Holoarctic, is the most common rodent of swamps and wetland in northern and central Poland. Across Poland runs a fragment of the southern limit of its compact range in Europe. There are also a number of isolated localities of root vole outside the main area which are remnants of the former, wider range.

In Europe, west of the compact range limit, the root vole can be found in south-western Holland on the islands Noord-Beveland, Schouven-Duiveland, Goere-Overflakkee, and Voorne Putten; in the vicinity of Rotterdam and Utrecht, and in north-eastern Holland in the province of Friesland and the islands Texel, Marken, Schokland and Ramspol (Wijngaarden and Zimmermann 1964). Between the province of Friesland and the Elbe M. oeconomus does not appear at present. Its locality on the island of Föhr (the North Frisian Islands), known since the 4th century, does not exist any more (Requate 1955). Remnants of $M$. oeconomus were discovered in early medieval excavations from Elisenhof on the western shores of the Schleswig-Holstein Peninsula. Studies of owl pellets from the Schleswig-Holstein area carried out in the years 1952-1970 did not show the presence of this species on the peninsula. Thus, it is probable that the localities in Itzehoe and Schleswig, recorded by E. Mohr in 1927, do not exist any more, either (Reichstein 1970).

South of the compact range limit in Europe, the root vole occurs on the Small Plain of Hungary: along the Danube (Źitny Ostrov, the Bratislava region, Kolarovo, Rajka) (Méhely 1908, Ehik 1928, Hanzák 1955, Kratochvíl and Rosický 1955, Feriancová- 
-Masárová and Hanák 1965, Binder and Štollmann 1975), and at Neusiedlersee (Bauer 1953, 1960); at Balaton (Vasvari 1950, Ehik 1953, Szunyoghy 1954); and between the Danube and the Tisa (Szunyoghy 1954, Topal 1963).

The goal of this work was to determine the present limit of the range of the root vole in Poland. Exact knowledge on this matter is an indispensable prerequisite for tracing changes that take place in the distribution of this species and for studies of the morphology and ecology of populations living at the edges of the range.

Earlier data on the occurrence of $M$. oeconomus in Poland, collected during various faunal, ecological and parasitological investigations, have been included in the "Atlas of Polish mammals" (Raczyński 1983).

\section{Methods and materials}

During the first stage of the research, 1975-1978, pellets of owls, almost exclusively barn owls Tyto alba were collected in areas of the presumed range limit of the root vole in Poland. At the start and in the course of the field work, the southernmost lacalities of this species were: in the east of Poland - Zwierzyniec, Górecko Kościelne, Guciów (Skuratowicz 1948), Krzyżanowice (Serafińska and Serafiński 1957), the Tomaszów Lubelski region (Cechowicz and Zwolski 1959), Lelów, Koniecpol and Wieluń (Sałata-Piłacińska 1977); in the west - Brodowice near Wołów (Rörig 1909), a locality between Zieliniec and Opole (Schlott 1930/31), Jemielna (Stein 1931), Domasław (Dorosz 1968), Osobowice (Chudoba and Humiński 1961), and Pęgów (Uttendörfer 1932). New data on the distribution of M.oeconomus at the edges of its range published during the field work (Markowski and Suskiewicz 1979) and after its completion (Raczyński 1983) could not have been taken into consideration in the choice of the research sites.

Attempts were made to bring up to date the data from the literature from before a few decades, because the range of the root vole may have changed as a result of advancing soil drainage.

Pellets were collected in church belfries and attics, usually in localities situated on river banks. Some 250 churches were searched. Pellets from 99 sites were collected. Out of them remnants of 33,107 individuals of mammals belonging to 28 species were prepared. The presence of the root vole was found in 29 localities, (Table 1).

After two years' break in the field work, towards the end of 1980, the trapping method was used to collect material. Trapping was carried out until the autumn of 1982 in selected biotopes complying with the requirements of $M$. oeconomus. When choosing a biotope, use was made of maps at a scale of 1:100000 and direct inspection in the field. Sometimes it was difficult to find a suitable biotope in a large area, and those found were widely scattered and had small areas, below 0.5 ha.

The mammals were caught using pitfalls, live-traps and snap-traps. They were set on paths of voles near their feeding grounds. The number of traps was not constant, it changed depending on the area of the biotope involved. Usually 20 to 30 traps were set. In a few localities studies were repeated several times. Trapping was carried out in 83 localities situated near the range limit of the root vole, and 526 mammals were caught, of which 334 of the family Arvicolidae. The root vole was caught in 16 localities (Fig. 1, Table 1).

\section{Remarks on the range limit of M. oeconomus in Poland}

On the basis of data from the literature and own research, the contemporary boundary of the range of the root vole in Poland was determined (Fig. 2). Generally, it diverts slightly from the direction of a parallel of lattitude and runs from the north-west to the south-east, roughly between $51^{\circ} \mathrm{N}$ in the west and $50^{\circ} \mathrm{N}$ in the east. This 
Table 1. The list of localities where Microtus oeconomus was searched for using the analysis of owl pellets (P) or trapping $(\mathrm{C})$.

Types of biotopes: I - water-logged meadows with patches of reed or tall sedge, mown at places; II - low bog with abundant herbaceous vegetation; III - water-logged, tussocky meadows with reed; IV - marshy banks of rivers, streams and ditches; V - water-logged acid sedge meadows; VI - mid-field mudy pools overgrown with reed and abundant herbs; VII - marshy banks of ponds; VIII - water-logged pastures with tussocks; IX - transition moors; X - mid-field ground depressions overgrown with reed.

\begin{tabular}{|c|c|c|c|c|c|c|c|c|}
\hline \multirow{3}{*}{ No. } & \multirow{3}{*}{ Locality } & & \multicolumn{2}{|c|}{ Number of specimens } & \multirow{3}{*}{ Biotope } & \multirow{3}{*}{$\begin{array}{l}\text { Year of } \\
\text { collection }\end{array}$} & \multirow{2}{*}{\multicolumn{2}{|c|}{$\begin{array}{l}\text { Co-ordinates of localities } \\
\text { of } M \text {. oeconomus }\end{array}$}} \\
\hline & & & \multirow{2}{*}{$\begin{array}{l}\text { Microtus } \\
\text { oeconomus }\end{array}$} & \multirow{2}{*}{$\begin{array}{l}\text { Microtus } \\
\text { agrestis }\end{array}$} & & & & \\
\hline & & & & & & & $\begin{array}{c}\text { geographical } \\
\text { E/N }\end{array}$ & UTM \\
\hline 1 & 2 & 3 & 4 & 5 & 6 & 7 & 8 & 9 \\
\hline 1 & Bożnów & $P$ & 3 & - & & 1977 & $15^{\circ} 20^{\prime} / 51^{\circ} 37^{\prime}$ & WT 21 \\
\hline 2 & Szprotawa & $\mathrm{P}$ & - & 2 & & 1977 & & \\
\hline 3 & Iłowa & $\mathrm{P}$ & - & 1 & & 1977 & & \\
\hline 4 & Klików & $\mathrm{C}$ & 3 & - & III & 1981 & $15^{\circ} 12^{\prime} / 51^{\circ} 28^{\prime}$ & WT 10 \\
\hline 5 & Sobolice & $\mathrm{P}$ & - & 2 & & 1981 & & \\
\hline 6. & Jagodzin & $\mathrm{C}$ & - & - & IV & 1980 & & \\
\hline 7 & Węgliniec & $\mathrm{C}$ & - & 4 & VII; IX & 1980 & & \\
\hline 8 & Przemków & $\mathrm{P}$ & 1 & - & & 1977 & $15^{\circ} 46^{\prime} / 51^{\circ} 32^{\prime}$ & WT 51 \\
\hline 9. & Jędrzychów & $P$ & 9 & 2 & & 1977 & $16^{\circ} 02^{\prime} / 51^{\circ} 27^{\prime}$ & WT 70 \\
\hline 10 & Lubin & $\mathrm{P}$ & 2 & 1 & & 1977 & $16^{\circ} 10^{\prime} / 51^{\circ} 24^{\prime}$ & WS 89 \\
\hline 11 & Tomaszów Górny & $\mathrm{P}$ & - & - & & 1977 & & \\
\hline 12 & Chojnów & $P$ & - & - & & 1977 & & \\
\hline 13 & Miłkowice & $\mathrm{P}$ & 1 & - & & 1977 & $16^{\circ} 04^{\prime} / 51^{\circ} 16^{\prime}$ & WS 77 \\
\hline 14 & Czerwona Woda & $\mathrm{P}$ & - & 4 & & 1977 & & \\
\hline 15. & Jędrzychowice & $\mathrm{C}$ & - & 5 & VII; IX & 1980 & & \\
\hline 16 & Żarska Wieś & $\mathrm{C}$ & - & 5 & III & 1980 & & \\
\hline 17 & Henryków Lubański & i $P$ & - & 6 & & 1977 & & \\
\hline 18 & Nawojów Łużycki & $\mathrm{C}$ & - & 1 & IV & 1980 & & \\
\hline 19 & Nowogrodziec & $\mathrm{P}$ & - & 5 & & 1977 & & \\
\hline 20 & Sulików & $\mathrm{C}$ & - & 7 & III & 1980 & & \\
\hline 21 & Studniska Dolne & $\mathrm{P}$ & - & 1 & & 1980 & & \\
\hline 22 & Rudzica & $\mathrm{P}$ & - & 1 & & 1977 & & \\
\hline 23 & Wyręba & $\mathrm{C}$ & - & 5 & III & 1980 & & \\
\hline 24 & Biedrzychowice & $P$ & - & 3 & & 1977 & & \\
\hline 25 & Oleszna Podgórska & $\mathrm{C}$ & - & 3 & III & 1980 & & \\
\hline 26 & Rakowice & $\mathrm{C}$ & - & 4 & VI & 1980 & & \\
\hline 27 & Niwnice & $\mathrm{C}$ & - & 3 & I & 1980 & & \\
\hline 28 & Lwówek Śląski & $\mathrm{P}, \mathrm{C}$ & - & $14(\mathrm{P})$ & I & $1977 ; 1980$ & & \\
\hline 291 & Pławna & $\mathrm{P}$ & - & 2 & & 1977 & & \\
\hline 30 & Marczów & $\mathrm{P}$ & - & 11 & & 1977 & & \\
\hline 31 & Siedlęcin & $\mathrm{P}$ & - & 1 & & 1977 & & \\
\hline 32 & Żerkowice & $\mathrm{P}$ & - & 2 & & 1977 & & \\
\hline 33 & Brunów & $\mathrm{C}$ & 4 & - & II & 1980 & $15^{\circ} 35^{\prime} / 51^{\circ} 09^{\prime}$ & WS 46 \\
\hline 34 & Gorczyca & $\mathrm{C}$ & - & 4 & VII & 1980 & & \\
\hline 35 & Czaple & C & - & - & VIII & 1980 & & \\
\hline 36 & Pielgrzymka & $\mathrm{P}, \mathrm{C}$ & $1(\mathrm{P}) ; 10(\mathrm{C})$ & $4(\mathrm{P})$ & VI & $1977 ; 1980$ & $15^{\circ} 48^{\prime} / 51^{\circ} 07^{\prime}$ & WS 56 \\
\hline 371 & Proboszczów & $\mathrm{P}$ & 1 & 3 & & 1980 & $15^{\circ} 47^{\prime} / 51^{\circ} 04^{\prime}$ & WS 55 \\
\hline 38 & Świerzawa & $\mathrm{P}$ & - & 1 & & 1980 & & \\
\hline 39 & Snowidza & $\mathrm{C}$ & 4 & - & II & 1980 & $16^{\circ} 15^{\prime} / 51^{\circ} 05^{\prime}$ & WS 95 \\
\hline 40 & Luboradz & C & 1 & - & IV & 1980 & $16^{\circ} 17^{\prime} / 51^{\circ} 04^{\prime}$ & WS 86 \\
\hline 41 - & Targoszyn & $P$ & - & 1 & & 1977 & & \\
\hline 42 & Wądroże & $\mathrm{P}$ & - & - & & 1977 & & \\
\hline
\end{tabular}




\begin{tabular}{|c|c|c|c|c|c|c|c|c|}
\hline 1 & 2 & 3 & 4 & 5 & 6 & 7 & 8 & 9 \\
\hline 43 & Malczyce & $\mathbf{P}$ & - & - & & 1977 & & \\
\hline 44 & Szczepanów & $P$ & - & - & & 1977 & & \\
\hline 45 & Pełcznica & $\mathrm{P}$ & - & 13 & & 1977 & & \\
\hline 46 & Piława & $\mathrm{C}$ & - & 9 & II & 1981 & & \\
\hline 47 & Mietków & $\mathrm{C}$ & - & 5 & II & 1981 & & \\
\hline 48 & Marcinowice & $\mathrm{C}$ & - & 3 & VIII & 1981 & & \\
\hline 49 & Klecin & $\mathrm{C}$ & - & 1 & I & 1981 & & \\
\hline 50 & Proszkowice & $\mathrm{C}$ & - & - & VIII & 1981 & & \\
\hline 51 & Sobótka & $\mathbf{P}$ & - & - & & 1977 & & \\
\hline 52 & Rogów Sobócki & P & - & - & & 1977 & & \\
\hline 53 & Tyniec & $\mathrm{P}$ & - & - & & 1977 & & \\
\hline 54 & Niwnik & $\mathrm{P}, \mathrm{C}$ & - & - & I & 1978 & & \\
\hline 55 & Marcinkowice & P & - & - & & 1978 & & \\
\hline 56 & Szydłowice & $\mathbf{P}$ & - & - & & 1978 & & \\
\hline 57 & Michałowice & $P$ & - & - & & 1978 & & \\
\hline 58 & Świerczów & $P$ & 2 & - & & 1977 & $17^{\circ} 41^{\prime} / 50^{\circ} 56^{\prime}$ & XS 94 \\
\hline 59 & Bogacica & $\mathrm{P}$ & 7 & 1 & & 1977 & $18^{\circ} 09^{\prime} / 50^{\circ} 58^{\prime}$ & BB 05 \\
\hline 60 & Fałkowice & $\mathrm{P}$ & 3 & 3 & & 1977 & $17^{\circ} 54^{\prime} / 50^{\circ} 58^{\prime}$ & YS 05 \\
\hline 61 & Kup & $\mathrm{P}$ & - & 7 & & 1977 & & \\
\hline 62 & Kobylno & $\mathrm{P}$ & 1 & 53 & & 1977 & $18^{\circ} 07^{\prime} / 50^{\circ} 47^{\prime}$ & BB 03 \\
\hline 63 & Popielów & $\mathrm{P}$ & - & 7 & & 1977 & & 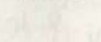 \\
\hline 64 & Dobrzeń Wielki & $\mathrm{P}$ & - & 3 & & 1977 & & \\
\hline 65 & Czarnowąsy & $\mathrm{P}$ & - & 20 & & 1977 & & \\
\hline 66 & Lewin Brzeski & $\mathrm{P}$ & - & - & & 1977 & & \\
\hline 67 & Szydłowiec Śląski & $\mathrm{P}$ & - & 1 & & 1977 & & \\
\hline 68 & Niemodlin & $\mathrm{P}, \mathrm{C}$ & - & $3(\mathrm{C})$ & III; IV & 1977; 1981 & & \\
\hline 69 & Tułowice & C & - & - & VII & 1981 & & $x^{2}$ \\
\hline 70 & Przechód & $P$ & - & 2 & & 1977 & & \\
\hline 71 & Chrząstowice & $\mathrm{C}$ & - & - & $\mathrm{X}$ & 1981 & & \\
\hline 72 & Lędziny & $\mathrm{C}$ & - & 4 & V & 1981 & & \\
\hline 73 & Gosławice & $\mathrm{C}$ & - & - & VII & 1981 & & \\
\hline 74 & Dębska Kuźnia & $\mathrm{C}$ & - & 1 & V & 1981 & & \\
\hline 75 & Biała & $\mathrm{P}$ & - & - & & 1977 & & \\
\hline 76 & Mokra & $\mathrm{P}$ & - & 1 & & 1977 & & \\
\hline 77 & Obrowiec & $\mathrm{P}$ & - & 5 & & 1977 & & \\
\hline 78 & Kłodnica & $P$ & - & - & & 1977 & & \\
\hline 79 & Cisek & $\mathrm{P}$ & - & - & & 1977 & & \\
\hline 80 & Roszowicki Las & $P$ & - & - & & 1977 & & \\
\hline 81 & Turze & $P$ & - & - & & 1977 & & \\
\hline 82 & Lubowice & $P$ & - & - & & 1977 & & \\
\hline 83 & Rudy & $P$ & - & 18 & & 1977 & & \\
\hline 84 & Markowice & P & - & - & & 1977 & & \\
\hline 85 & Ciasna & $\mathrm{C}$ & - & 2 & VIII & 1981 & & \\
\hline 86 & Lisów (a) & $\mathrm{C}$ & 24 & 2 & I; III; IV & $1981 ; 1982$ & $18^{\circ} 43^{\prime} / 50^{\circ} 43^{\prime}$ & CB 42 \\
\hline & (b) & $\mathrm{C}$ & 2 & 8 & IV; V; IX & 1982 & $18^{\circ} 43^{\prime} / 50^{\circ} 43^{\prime}$ & CB 42 \\
\hline 87 & Blachownia & $\mathrm{C}$ & 6 & - & III & 1981 & $18^{\circ} 57^{\prime} / 50^{\circ} 47^{\prime}$ & CB 52 \\
\hline 88 & Kośmidry & $\mathrm{C}$ & - & 2 & IX & 1981 & & 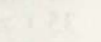 \\
\hline 89 & Mochała & $\mathrm{C}$ & - & 4 & III & 1982 & & \\
\hline 90 & Hadra & $\mathrm{C}$ & - & 6 & III & 1982 & c & \\
\hline 91 & Boronów & $\mathrm{C}$ & - & 6 & IV; VIII & 1982 & & \\
\hline 92 & Psary & $\mathrm{C}$ & - & 5 & II & 1982 & & \\
\hline 93 & Wierzbie & $\mathrm{C}$ & - & 4 & III & 1981 & & \\
\hline 94 & Koszęcin & $\mathrm{C}$ & - & 7 & III & 1981 & & \\
\hline 95 & Bagno & C & - & 1 & $\mathrm{X}$ & 1981 & & \\
\hline
\end{tabular}




\begin{tabular}{|c|c|c|c|c|c|c|c|c|}
\hline 1 & 2 & 3 & 4 & 5 & 6 & 7 & 8 & 9 \\
\hline 96 & Woźniki & $\mathrm{C}$ & - & 5 & III & 1981 & & \\
\hline 97 & Winowno & $\mathrm{C}$ & - & 3 & III & 1981 & & \\
\hline 98 & Koziegłówki & $\mathrm{P}$ & - & 1 & & 1977 & & \\
\hline 99 & Kuźnica Pusta & $\mathrm{C}$ & - & - & IV & 1981 & & \\
\hline 100 & Tworóg & $\mathrm{C}$ & - & - & IV & 1981 & & \\
\hline 101 & Wieszowa & $\mathrm{P}$ & - & 8 & & 1977 & & \\
\hline 102 & Niezdara & $\mathrm{C}$ & - & - & IV & 1981 & & \\
\hline $102 a$ & Stare Tarnowice & $\mathbf{P}$ & - & 10 & & 1977 & & \\
\hline 103 & Siewierz & $\mathrm{P}$ & - & - & & 1977 & & \\
\hline 104 & Koniecpol & $\mathrm{P}$ & 8 & - & & 1975 & $19^{\circ} 42^{\prime} / 50^{\circ} 47^{\prime}$ & DB 02 \\
\hline 105 & Lelów & $\mathrm{P}, \mathrm{C}$ & $2(\mathrm{C}) ; 5(\mathrm{P})$ & - & II & 1975 & $19^{\circ} 35^{\prime} / 50^{\circ} 41^{\prime}$ & DB 01 \\
\hline 106 & Julianka & C & 1 & - & I & 1978 & $19^{\circ} 28^{\prime} / 50^{\circ} 46^{\prime}$ & CВ 01 \\
\hline 107 & Udórz & $\mathrm{C}$ & 1 & - & II & 1981 & $19^{\circ} 46^{\prime} / 50^{\circ} 28^{\prime}$ & DA 09 \\
\hline 108 & Zawiercie & $\mathrm{C}$ & 2 & - & IV & 1981 & $19^{\circ} 25^{\prime} / 50^{\circ} 30^{\prime}$ & CA 89 \\
\hline 109 & Piotrkowice & $\mathrm{P}$ & 2 & - & & 1976 & $20^{\circ} 15^{\prime} / 50^{\circ} 31^{\prime}$ & DA 49 \\
\hline 110 & Jędrzejów & $\mathrm{P}$ & 4 & - & & 1976 & $20^{\circ} 18^{\prime} / 50^{\circ} 39^{\prime}$ & DB 51 \\
\hline 111 & Kazanów & $\mathrm{P}$ & 1 & - & & 1976 & $20^{\circ} 20^{\prime} / 51^{\circ} 10^{\prime}$ & DB 57 \\
\hline 112 & Chlewiska & $\mathrm{P}$ & 2 & 1 & & 1976 & $20^{\circ} 43^{\prime} / 51^{\circ} 15^{\prime}$ & DB 87 \\
\hline 113 & Jastrząb & $\mathrm{P}$ & 8 & 2 & & 1976 & $20^{\circ} 57^{\prime} / 51^{\circ} 15^{\prime}$ & DB 97 \\
\hline 114 & Iłża & $\mathrm{P}$ & 10 & - & & 1976 & $21^{\circ} 15^{\prime} / 51^{\circ} 10^{\prime}$ & EB 16 \\
\hline 115 & Grabowiec & $\mathrm{P}$ & 6 & 1 & & 1976 & $21^{\circ} 21^{\prime} / 51^{\circ} 06^{\prime}$ & EB 25 \\
\hline 116 & Bolmin & $\mathrm{P}$ & 2 & - & & 1976 & $20^{\circ} 22^{\prime} / 50^{\circ} 49^{\prime}$ & DB 52 \\
\hline 117 & Strawczyn & $\mathrm{P}$ & 1 & 7 & & 1976 & $20^{\circ} 26^{\prime} / 50^{\circ} 57^{\prime}$ & DB 54 \\
\hline 118 & Chełmce & $\mathrm{P}$ & - & 2 & & 1976 & & \\
\hline 119 & Piekoszów & $\mathrm{P}$ & - & - & & 1976 & & \\
\hline 120 & Podegrodzie & $\mathrm{C}$ & - & 8 & IV; V & 1981 & & \\
\hline 121 & Tumlin & $\mathrm{P}$ & - & - & & 1976 & & \\
\hline 122 & Masłów & $\mathrm{P}$ & - & - & & 1976 & & \\
\hline 123 & Brzezinki & $\mathrm{P}$ & - & - & & 1976 & & \\
\hline 124 & Krajno & $\mathrm{P}$ & - & - & & 1976 & & \\
\hline 125 & Św. Katarzyna & C & - & 11 & V; IX & $1975-1978$ & & \\
\hline 126 & Makoszyn & $\mathrm{P}$ & - & 9 & & 1976 & & \\
\hline 127 & Słopiec Szlachecki & $\mathrm{C}$ & - & 8 & IX & 1982 & & \\
\hline 128 & Mostki & C & - & 1 & V & 1978 & & \\
\hline 129 & Kunów & $\mathrm{P}$ & 5 & - & & 1976 & $21^{\circ} 17^{\prime} / 50^{\circ} 57^{\prime}$ & EB 24 \\
\hline 130 & Krynki & $\mathrm{P}$ & - & 1 & & 1976 & & \\
\hline 131 & Momina & $\mathrm{P}$ & - & - & & 1975 & & \\
\hline 132 & Mychów & $\mathrm{P}$ & - & - & & 1975 & & \\
\hline 133 & Waśniów & $\mathrm{P}$ & - & 3 & & 1975 & & \\
\hline 134 & Szewna & $\mathrm{P}$ & - & - & & 1975 & & \\
\hline 135 & Baćkowice & $\mathrm{P}$ & - & - & & 1977 & & \\
\hline 136 & Opatów & $\mathrm{P}$ & - & - & & 1977 & & \\
\hline 137 & Iwaniska & $\mathrm{P}$ & - & - & & 1976 & & \\
\hline 138 & Zęborzyn & $\mathrm{P}$ & 2 & - & & 1976 & $21^{\circ} 43^{\prime} / 51^{\circ} 03^{\prime}$ & EB 45 \\
\hline 139 & Tarłów & $\mathrm{P}$ & 2 & - & & 1976 & $21^{\circ} 43^{\prime} / 51^{\circ} 01^{\prime}$ & EB 24 \\
\hline 140 & Słupia Nadbrzeżna & $\mathrm{P}$ & 5 & - & & 1976 & $21^{\circ} 48^{\prime} / 50^{\circ} 57^{\prime}$ & EB 54 \\
\hline 141 & Zawichost & $\mathrm{P}$ & 1 & 2 & & 1976 & $21^{\circ} 52^{\prime} / 50^{\circ} 49^{\prime}$ & EB 53 \\
\hline 142 & Pińczów & $\mathrm{P}$ & 3 & - & & 1976 & $20^{\circ} 33^{\prime} / 50^{\circ} 31^{\prime}$ & DA 69 \\
\hline 143 & Wiślica & $\mathrm{C}$ & - & - & V; VII & 1982 & & \\
\hline 144 & Gorysławice & $\mathrm{C}$ & - & - & V & 1982 & & \\
\hline 145 & Latanice & $\mathrm{C}$ & - & - & VII; VIII & 1982 & & \\
\hline 146 & Brzezie & $\mathrm{C}$ & - & - & VIII & 1982 & & \\
\hline 147 & Chmielnik & $\mathrm{C}$ & 7 & - & II & 1981 & $20^{\circ} 48^{\prime} / 50^{\circ} 36^{\prime}$ & DB 80 \\
\hline 148 & Raków (a) & $\mathrm{C}$ & 3 & - & II; IV & 1981 & $21^{\circ} 03^{\prime} / 50^{\circ} 41^{\prime}$ & EB 01 \\
\hline
\end{tabular}




\begin{tabular}{|c|c|c|c|c|c|c|c|c|}
\hline 1 & 2 & 3 & 4 & 5 & 6 & 7 & 8 & 9 \\
\hline & Raków (b) & $\mathrm{C}$ & - & - & IV; VIII & 1981 & & 20 \\
\hline 149 & Szydłów & $P$ & - & - & & 1975 & & ate \\
\hline 150 & Szczaworyż & $P$ & - & - & & 1975 & & 20 \\
\hline 151 & Rytwiany & $\mathrm{C}$ & - & 1 & VII & 1979 & & 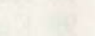 \\
\hline 152 & Słomniki & $\mathrm{C}$ & - & - & IV & 1982 & & ant \\
\hline 153 & Ilkowice & $\mathrm{C}$ & - & - & IV & 1982 & & 40 \\
\hline 154 & Janków & $\mathrm{C}$ & - & - & IX & 1982 & & 60 \\
\hline 155 & Skalbmierz & $\mathrm{C}$ & - & - & IV & 1982 & & $e^{2}=$ \\
\hline 156 & Ispina & $\mathrm{C}$ & - & 2 & II & 1982 & & (10) \\
\hline 157 & Ostrowce & $\mathrm{C}$ & - & - & VIII & 1981 & & a) \\
\hline 158 & Świniary & $\mathrm{C}$ & - & - & VII & 1981 & & (5) \\
\hline 159 & Pacanów & $\mathrm{C}$ & - & - & V & 1981 & & ant \\
\hline 160 & Szewce & $\mathrm{C}$ & - & - & V & 1981 & & (n) \\
\hline 161 & Samborzec & $\mathrm{C}$ & - & - & IV & 1981 & & 200 \\
\hline 162 & Skotniki & $\mathrm{P}, \mathrm{C}$ & - & - & IV; V & $1976 ; 1981$ & & 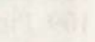 \\
\hline 163 & Koprzywnica & $\mathrm{P}$ & - & - & & 1976 & & an \\
\hline 164 & Jamnica & $\mathrm{C}$ & - & 1 & III & 1981 & & \\
\hline 165 & Budy Stalowe & C & - & 4 & III; IV & 1981 & & 1 \\
\hline 166 & Nowy Nart & $\mathrm{C}$ & - & 8 & I & 1981 & & enter \\
\hline 167 & Nowa Wieś & C & - & 3 & III; IV & 1981 & & \\
\hline 168 & Lazów & C & - & 1 & III; IV & 1981 & & 27 \\
\hline 169 & Kolno & $\mathrm{C}$ & - & 3 & III & 1981 & & \\
\hline 170 & Łukowa & $\mathrm{P}$ & 9 & 9 & & 1979 & $22^{\circ} 57^{\prime} / 50^{\circ} 22^{\prime}$ & FA 38 \\
\hline 171 & Lubaczów & $\mathrm{C}$ & 3 & - & I & 1981 & $23^{\circ} 05^{\prime} / 50^{\circ} 09^{\prime}$ & FA 55 \\
\hline 172 & Wólka Krowicka & $\mathrm{C}$ & 9 & - & I & 1981 & $23^{\circ} 09^{\prime} / 50^{\circ} 05^{\prime}$ & FA 54 \\
\hline 173 & Makowisko & $\mathrm{C}$ & - & 1 & VI & 1981 & & \\
\hline 174 & Zapałów & C & - & 3 & III & 1981 & & \\
\hline 175 & Wólka Zapałowska & C & 1 & 3 & III & 1981 & $22^{\circ} 54^{\prime} / 50^{\circ} 06^{\prime}$ & FA 45 \\
\hline 176 & Nowa Grobla & $\mathrm{C}$ & - & 1 & IV & 1981 & & \\
\hline
\end{tabular}

inclination, parallelling the southern boundary of the compact range of the animal in Europe (Tast 1982), may be a result of its approaching the western limit of the range, along the lower Elbe [in East Germany the southern limit of the range of M. oeconomus runs from the north-west to the south-east (Jorga 1971)].

The range limit of the root vole in Poland is not a regular but rather a broken line. Simplifying, it reaches the Sudeten in the west. However, this species could not be found in the southern Lower Silesian Woods (Bory Dolnośląskie) or in the area of Izerskie Foothills (Pogórze Izerskie), despite its occurrence both west (Caminau $14^{\circ} 20^{\prime} \mathrm{E}, 51^{\circ} 20^{\prime} \mathrm{N}$ ) (Creutz and Schipke 1980) and east of this region (localities 33, 36 and 37 in Kaczawskie Foothills [Pogórze Kaczawskie]). Further east, in the area of the Wrocław Plain and Wrocław Ice-marginal Valley (Pradolina Wrocławska) the boundary has a west-east direction. (Names and boundaries of geographical regions after Kondracki 1978). The occurrence of the root vole south of it may be made impossible by two factors: a warm, Atlantic-type climate, and intensive agricultural land use. River engineering and drainage, practised here since a long time, have led to such a drastic disappearance of wet biotopes that also the substitute of the root vole, the field vole Microtus agrestis was found to be missing from most pellets coming from this region. No root voles were found to occur south of localities known from the 

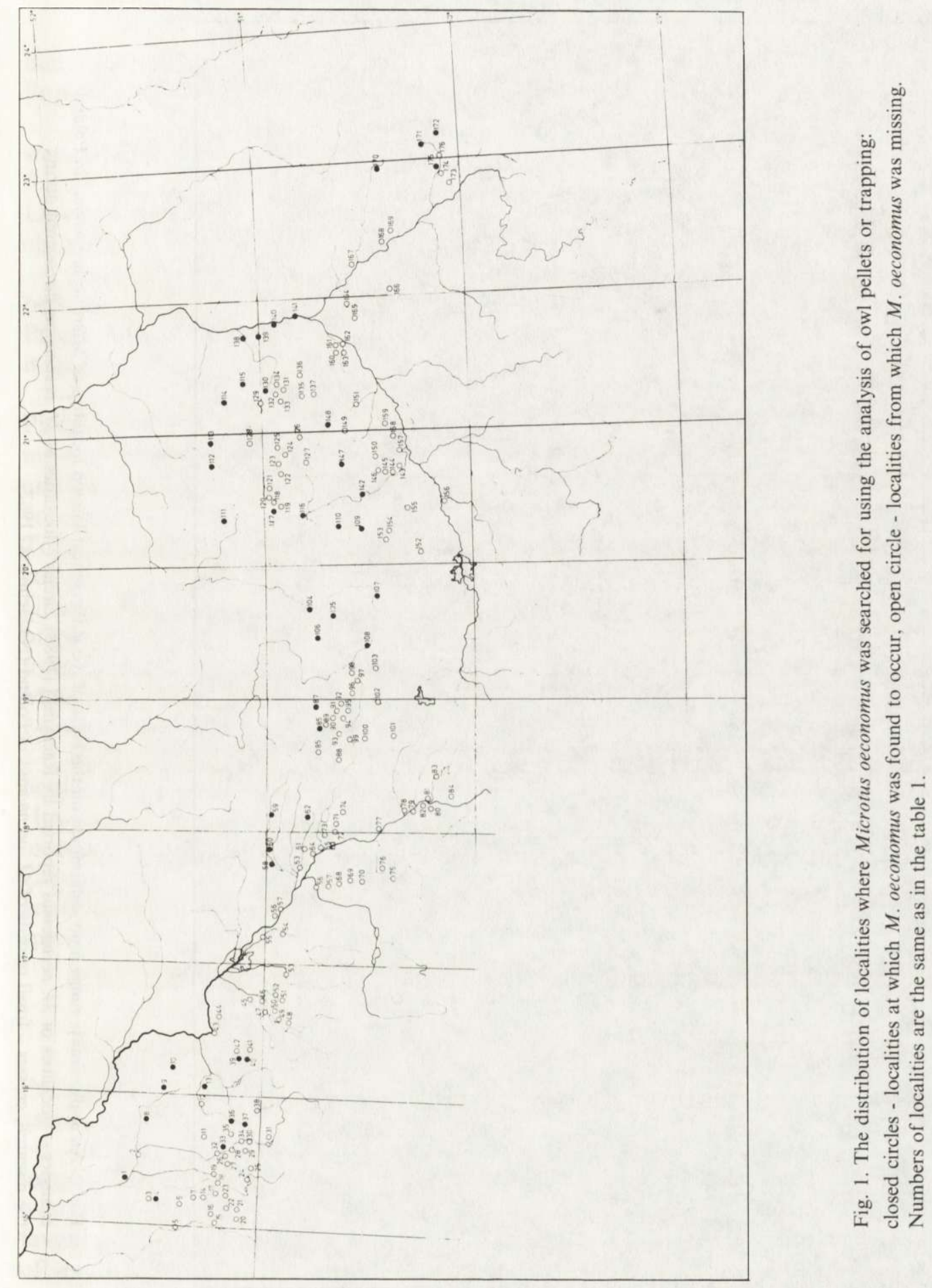

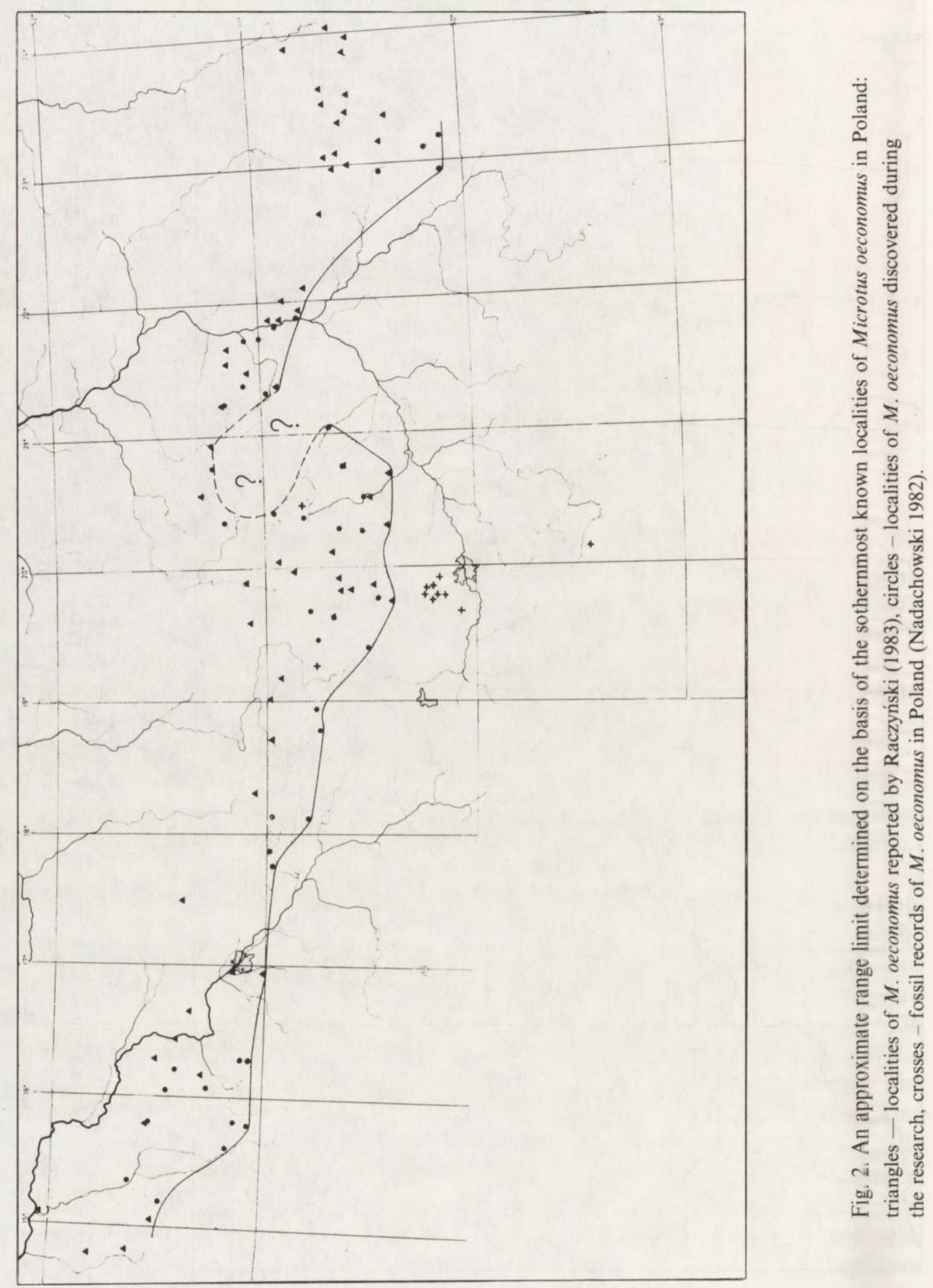
literature: Osobowice (Chudoba and Humiński 1961), Domasław (Dorosz 1968), and Pęgów (Uttendörfer 1932).

East of the Odra the boundary turns south-east. It coincides roughly with the watershed between the Stobrawa and Liswarta drainage basins, and that of the Mała Panew. However, no traces of the root vole were found in the uppermost reaches of the Liswarta, despite a relative continuity of waterlogged meadows and reed along its channel.

Farther east the boundary turns clearly south, coinciding with the watershed between the headwaters of the Warta and Pilica, and the drainage basins of the Biała Przemsza and Szreniawa. Then it runs straight east to the Nida river valley. Farther on it probably shifts north, parallelling the upper Vistula valley, and reaches Zawichost.

No root voles were found inside the triangle determined by the extreme localities at Pińczów (no. 142), Zawichost (no. 141) and Wólka Zapałowska (no. 175), and covering most of the Sandomierz Basin. This confirmed the negative results of Kołton (1957) and Cais (1963), who searched for this species in pellets collected in that area. The root vole was not found in the Świętokrzyskie Mountains or the Sandomierz Upland either. Together with the triangle mentioned above, they form a large area penetrating into the compact range of the species (Fig. 2). No root voles were found on the Sandomierz Upland in abundant pellet materials studied by Włodarczyk (1963) or collected in preparation of the present article. However, this species was reported to occur in pellets from Szewna (a locality on the fringe of the Sandomierz Upland) collected by the Mammal Research Institute in 1963 (Raczyński 1983). In the sizeable material I collected in this locality in 1975 there was not a single specimen of $M$. oeconomus.

East of the lower San valley the range limit turns south. The root vole was found to be absent from three localities studied in this area. The species trapped was M. agrestis. However, a bit farther east, in the Tarnogród Plateau region, the southernmost localities of the root vole in Poland were recorded: Lubaczów (no. 171), Wólka Zapałowska (no. 175), and Wólka Krowicka (no. 172). A bit more to the south, just across the state boundary or maybe still in Poland, are probably other localities of this species.

\section{Discussion}

There are a number of factors controlling the range of the root vole in Poland. Probably the most important are climatic conditions, man-made factors, and their associated biotope factors.

As to the climatic factors, there is a combined impact of the increase in temperature southwards and the intensification of the oceanic character of the climate westwards. It is seemingly incomprehensible that the "oceanity" of the climate does not favour the occurrence of this particularly hygrophilous species. There is a similar case of Apodemus agrarius. Its expansion westwards also seems to be checked by the growing impact of the Atlantic climate (Pelz 1980). The range of the root vole in Asia 
(Corbet 1978) proves that under a continental climate it may extend much farther south. It may have been a more continental climate of the Plain of Hungary in comparison with the neighbouring areas (Bauer 1960) that enabled the survival of relic localities of the subspecies $M$. oeconomus mehelyi there, in very comfortable biotope conditions (Ehik 1928).

The continental climate is characterised by stable meteorological conditions. The snow cover persisting over a considerable part of the year provides a shelter under which root voles can feed and move safely. Changes in temperature following changes in atmospheric pressure systems bring about sudden thaws, changes in the level of ground water, and the inundation of biotopes situated on lower grounds, and hence, of nests and hiding-places of root voles. Populations living in the centre of the range do not suffer great losses during inundation - they move to neighbouring biotopes for a time (Raczyński et al. 1983). Under the sub-optimal conditions of range limit, sudden and frequent changes in temperature during winter and the short duration of the snow cover are especially harmful to this species. In Poland it usually lives in small environmental enclaves surrounded by cultivated fields; hence, it has no natural refuges characteristic of extensive wetland.

The range of the root vole in Europe has dwindled considerably (Tast 1982). This is evidenced by numerous fossil and subfossil findings of this species in areas where it is not recorded at present (Requate 1955, Kowalski 1959, 1961, Janossy 1960, Reichstein 1970, 1972, Nadachowski 1982), as well as by the existence of isolated refuges outside the limits of the compact range.

The rate at which the distribution of the root vole shrinks in modern times may be speed up dramatically by human activity, mainly the elimination from the landscape of environments typical of this species (the reclamation of marshland, the regulation of rivers and streams, peat exploitation, and even turning peat bogs into fish ponds). In all probability it is human impact that has crucially contributed to the disappearance of the root vole from much of the Wrocław Plain and the Wrocław Ice-marginal Valley (Wrocław Pradolina). A comparison of the range of the root vole with a map of low bogs in Poland (Fig. 3) suggests that with the dwindling of these environments the range of this species will shrink too.

Owing to the fragmentary character of the previous data on the occurrence of the root vole in the south of Poland, it is impossible to determine the changes that have taken place in its range over the decades, or even to prove that such changes have taken place at all. The animal was still recorded near most of the southern localities known from the older literature. This concerns the precisely located sites in Silesia, the Nida river valley, and the Zamość region. It turned out, however, that they usually did not lie on the very borderline of the range. In some cases attempts to verify older localities failed. Sometimes these were localities not altogether reliable (Zabrze - Krumbiegel 1948), or described vaguely, e.g. Oppelner Land reported by Schlott (1930/31) and quoted by later authors as Opole. Schaefer (1931) claims that the locality mentioned by Schlott was situated between Zieliniec (Gründorf) and Opole, hence near the locality 


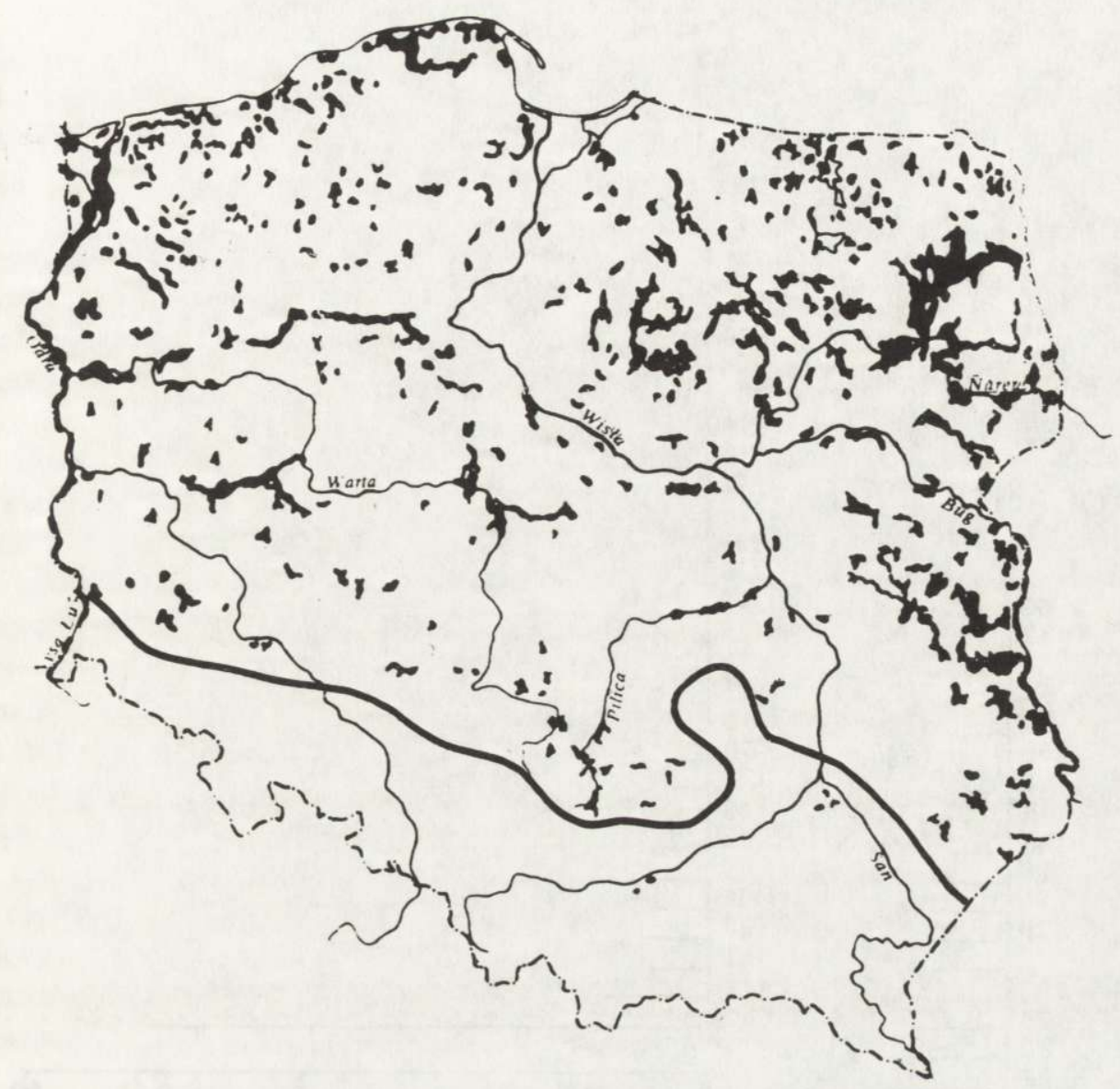

Fig. 3. The southern range limit of Microtus oeconomus seen against a map of major low bogs in Poland (Jasnowski 1975).

no. 62 (Kobylno) and not in Opole as reported by e.g. Zimmermann (1942). In other cases [Szewna (Raczyński 1983) or the upper Pilica valley (Markowski and Suskiewicz 1979)] the failure of the latest search need not be a conclusive proof of the absence of the root vole from these areas.

The most probable phenomenon to occur in near future is a perceptible change in the range limit in Kaczawskie Foothills (Pogórze Kaczawskie) and the Częstochowa Upland, where the localities of $M$. oeconomus are scattered widely and occupy small environmental enclaves habitable to this species.

It may be especially interesting to carry out further, more detailed studies in the Liswarta river valley. The range of the root vole ends here in the area of Lisów (locality no 86), despite the fact that there is a belt of biotopes suitable for this species extending southwards, along the river course.

South of the range of the root vole, localities it used to inhabit and that are typical 


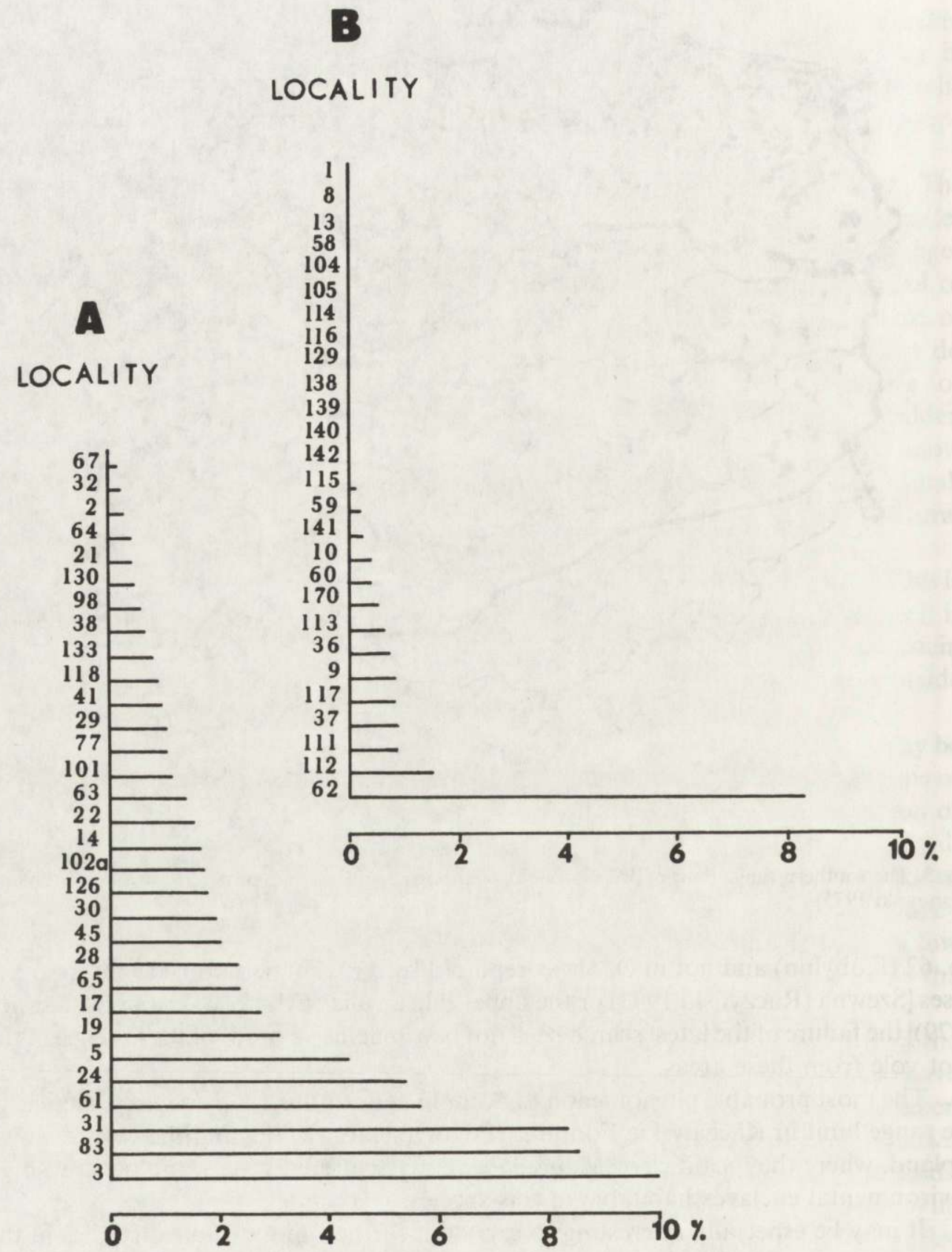

Fig. 4. The proportion of Microtus agrestis in the food of owls from localities at which M. oeconomus occurred (B) and from those where it was not found in the pellets studied (A). Localities at which neither of the species was found are omitted. 
of this species are now usually being colonised by the field vole Microtus agrestis. In this part of its range where it has been freed of the competition of the root vole, it colonises waterlogged open biotopes which it used to lose to the competitor. Thus, outside the range of the root vole, the field vole becomes a much more common mammal outnumbering the rival, which is reflected in trapping results (Table 1) and the pellet material analysed (Fig. 4). Only in two localities (nos. 86 and 175), bordering on a wood, both species were trapped. Outside the range, a great number of biotopes in which the field vole was trapped were typical open ones, often at a considerable distance from a wood (localities no. 15, 16, 20, 23, 26, 27, 46, 48, 68, 72, 74, 89, 90, 92, and 120 - Table 1, Fig. 1).

The results of trapping carried out near the limit of its range show that in this area $M$. oеconomus prefers unforested eutrophic waterlogged land with abundant herbaceous vegetation, usually partly overgrown with the reed Phragmites communis. It was not caught in localities tending to become transition moors of a mesotrophic character. This confirms the observations of Zimmermann (1942) concerning biotope preferences of $M$. agrestis and $M$. oeconomus, while contradicting trapping results obtained on a high bog at Chlebowo (Rachowiak 1989). Perhaps it is due to the fact that in the biotopes of transition moors and high bogs the root vole gives way to the field vole, at least near the limit of its range, that $M$. oeconomus is not recorded in the Świętokrzyskie Mountains and in the southern part of the Lower Silesian Woods.

On the basis of the data obtained during the field work a possibly precise limit of the range of the root vole in Poland was determined. It is probable that this limit undergoes periodic and also permanent shifts. A precise knowledge of its location at a specific time may be a starting-point for further observations of its shifts and the behaviour of frontier populations.

Acknowledgements: This work, conducted with his kind interest, I would like to dedicate to the memory of my Teacher, Professor W. Skuratowicz. I am grateful for critical but revealing remarks to Prof. Z. Pucek and Dr. A. L. Ruprecht. Particular thanks for co-operation in the field without which the collection of this material would have been impossible are due to Mrs B. Trzmielewska, Mr J. Skibiński, Dr. A. Nowosad, Dr. A. Głazaczow, and my husband.

\section{References}

Bauer K. 1953. Zur Kenntnis von Microtus oeconomus mehelyi Ehik. Zool. Jahrb. (Syst.) 82: 70 -94.

Bauer K. 1960. Die Säugetiere des Neusiedlersee - Gebites (Österreich). Bonn. zool. Beitr. 11: 141-343.

Binder P. and Štollmann A. 1975. Prispevok k rozšireniu hraboša severskeho stredoeuropskeho (Microtus oeconomus mehelyi Ehik, 1928) na Slovensku. Lynx 17: 19-22.

Cais L. 1963. Badania nad składem pokarmu kilku gatunków sów. Zesz. nauk. UAM Poznań 44: 3-21.

Cechowicz W. and Zwolski W. 1959. Zur Leptospirose auf dem Lande in der Lubliner Gegend. IV. Zoologisch-ökologische Forschungen über kleine Säugetiere in den Naturherden der Leptospirose auf dem Lande. Arch. exp. Veterinärmed., Leipzig 13: 195-199.

Chudoba S. and Humiński S. 1961. Podwrocławskie tereny nawożone miejskimi wodami ściekowymi jako biotop owadożernych i gryzoni. Prz. zool. 5: 132-137.

Corbet G. B. 1978. The Mammals of the Palearctic Region: a taxonomic rewiev. British Museum (Natural 
History). Cornell Univ. Press, London: 1-314.

Creutz G. and Schipke R. 1980. Erstfund der Nordischen Wühlmaus (Microtus oeconomus) im sachsichen Teil der Oberlausitz. Abh. Ber. Naturkundemus., Görlitz 53: 21-22.

Dorosz J. 1968. Helminth parasites of small rodents living in areas irrigated by urban sevage of Wrocław. Acta parasit. pol. 15: $375-496$.

Ehik J. 1928. Einige Daten zur Säugetierkunde Ungarns. Ann. Mus. Nat. Hung. 25: 195-203.

Ehik J. 1953. Ergänzende Angaben zur Kenntnis der Nordischen Wühlmaus Microtus ratticeps mehelyi Ehik, 1928 in Ungarn. Säugetierk. Mitt. 1: 28-29.

Feriancová-Masarová Z. and Hanak V. 1965. Stavovce Slovenska IV. Cicavce. VSAV Bratislava,: 1 - 334.

Hanzák J. 1955. K otazce vyskytu hraboše severniho, Microtus oeconomus méhelyi Ehik v Českoslevensku. Čas. Nár. Musea přir. 123: 164-167.

Janossy D. 1960. Nacheiszeitliche Wandlungen der Kleinsäugerfauna Ungarns. Zool. Anz. 164: 114-121. Jasnowski M. 1975. Torfowiska i tereny bagienne w Polsce. [In: Bagna kuli ziemskiej. N. Kac, ed.] PWN, Warszawa: 1-144.

Jorga W. 1971. Die südliche Verbreitungsgränze der Nordischen Wühlmaus, Microtus oeconomus auf dem Gebiet der DDR und Bemerkungen zu deren Grenzpopulationen. Hercynia, N. F. 8: 286-306.

Kołton W. 1957. Analiza wypluwek sowy płomykówki Tyto alba guttata Brehm z terenu wideł Sanu i Wisły. M. Sc. thesis, Zakł. Anat. Porówn. UMCS, Lublin: 1-28.

Kondracki J. 1978. Geografia fizyczna Polski. PWN, Warszawa: 1-463.

Kowalski K. 1959. Katalog ssaków plejstocenu Polski. PWN, Warszawa - Wrocław: 1-267.

Kowalski K. 1961. Plejstoceńskie gryzonie Jaskini Nietoperzowej w Polsce. Folia quatern. 5: 1-22.

Kratochvil J. and Rosický B. 1955. Hraboš severni (Microtus oeconomus), relikt zviřeny z doby ledove v CSR. Práce Brněnske Základny Československe Akademie Véd 27: 33-72.

Krumbiegel I. 1948. Eurasische Mäuse als Seuchenüberträger, ihre Verbreitung und geomedizinische Bedetung. Beitr. Hygiene u. Epidem. 3: 20-28.

Markowski J. and Suskiewicz B. 1979. Ssaki (Mammalia) doliny rzeki Pilicy. Acta Univ. Lodz., Folia Zool. Antropol. 1: 67-94.

Méhely L. 1908. Ket uj pocokfaj a magyar faunaban. Allatt. Közl., Budapest 7: 3-14.

Nadachowski A. 1982. Late Quarternary rodents of Poland with special reference to morphotype dentition analysis of voles. PWN, Kraków - Warszawa: 1-108.

Pelz H. J. 1980. Populationsökologie der Brandmaus Apodemus agrarius (Pallas, 1771), an ihrer westlichen Verbreitungsgrenze in Osthessen. II. Biotopwahl und Verhalten. Z. angew. Zool. 67: 257-278.

Rachowiak P. 1989. Drobne ssaki wybranych biotopów torfowiska „Bagno” w Chlebowie. Bad. fizj. Pol. Zach., C 38: 85-98.

Raczyński J. 1983. Microtus oeconomus (Pallas, 1776). [In: Atlas of Polish mammals. Z. Pucek and J. Raczyński, eds]. PWN, Warszawa: 111 -112, map: 99.

Raczyński J., Fedyk S., Gębczyńska Z. and Pucek M. 1983. Drobne ssaki środkowego i dolnego basenu Biebrzy. Zesz. probl. Post. Nauk. roln. 255: 297-328.

Reichstein H. 1970. Zum Vorkommen der Nordischen Wühlmaus, Microtus oeconomus (Pallas, 1776) in historischer Zeit in Schleswig-Holstein (Norddeutschland). Z. Säugetierk. 35: 147-159.

Reichstein H. 1972. Ein Nachweis der Nordischen Wühlmaus, Microtus oeconomus (Pallas, 1776) aus dem vorgeschichtlichen Nordwest-Deutschland. Z. Säugetierk. 37: 98-101.

Requate H. 1955. Ein Fund von Microtus oeconomus stimmingi Nehring, 1899, aus den 4. Jahrhundert auf der Insel Fohr. Säugetierkdl. Mitt. 3: 123-124.

Rörig R. 1909. Die nordische Wühlratte Arvicola ratticeps Keys. et Blas. in Deutschland und ihre Verwandtschaft mit den russischen Arvicoliden. Arb. Kaiserl. Biol. Anst. Land - Forst - wirtsch., Berlin 7: $429-472$. 
Sałata-Piłacińska B. 1977. Ssaki w pokarmie płomykówki (Tyto alba guttata Brehm) z terenu Polski, ze szczególnym uwzględnieniem zachodniej części kraju. Bad. fizjogr. Pol. zach., C 30: 7-27.

Schaefer H. 1931. Zur Verbreitung von Microtus ratticeps in Schlesien. Z. Säugetierk. 6: 225.

Schlott M. 1930/31. Kleinsäugetierstudien aus Oberschlesien. Ostdt. Naturwart. Liegnitz 3: 104-106.

Serafińska J. and Serafiński W. 1957. Kilka rzadszych lub mniej znanych form ssaków z Doliny Nidy. Acta zool. cracov. 2: 207-217.

Skuratowicz W. 1948. Badania nad fauną ssaków Zamojszczyzny. Fragm. faun. 5: 233-292.

Stein G. 1931. Beiträge zur Kenntnis einiger mitteleuropäischer Säuger. Mitt. zool. Mus. Berlin 17: $273-298$.

Szunyoghy J. 1954. Beiträge zur Kenntnis der Verbreitung sowie der Gehörknöchelchen und des Penisknochens von Microtus oeconomus mehelyi Ehik. Allat. Közl., Budapest 24: 225-230.

Tast J. 1982. Microtus oeconomus (Pallas, 1776) -Nordische Wühlmaus, Sumpfmaus. [In: Handbuch der Säugetiere Europas. J. Niethammer and F. Krapp, eds]. Akad. Verlagsgeselsch., Wiesbaden, 2, 1: $374-396$.

Topal G. 1963. Ujabb adat a Microtus oeconomus mehelyi Ehik magyarorszagi elöfordulasahoz es a Tisza menti (Saser) elöfordulas cafolata. Vertebr. Hung. 5: 159-164.

Uttendörfer O. 1932. Einige Ergebnisse von Gewölluntersuchungen. Z. Säugetierk. 7: 259-261.

Vasvari N. 1950. Microtus ratticeps as food of birds. Aquila 51-54: 85-86.

Wijngaarden A. and Zimmermann K. 1964. Zur Kenntnis von Microtus oeconomus arenicola (de Selys Longchamps, 1841). Z. Säugetierk. 30: 129-136.

Włodarczyk L. 1963. Badania nad składem pokarmu płomykówki (Tyto alba guttata Brehm) i puszczyka (Strix aluco L.) w okolicach Sandomierza w latach 1961-1962. Master Thesis, Zakł. Zool. Syst. UAM Poznań: 1-35.

Zimmermann K. 1942. Zur Kenntnis von Microtus oeconomus. Arch. Naturgesch. N. F. 11: 174-197.

Received 5 October 1988, accepted 20 July 1990. 